ECONOMICS

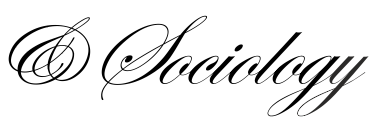

\author{
Orkhan Nadirov, \\ Tomas Bata University in Zlin, \\ Zlin, Czech Repuplic, \\ E-mail:nadirov@fame.utb.cz. \\ Khatai Aliyev, \\ Azrerbaijan State Economic \\ University (UNEC), \\ Baku, Azerbaijan, \\ E-mail:khatai.aliyer@unec.edu.az
}

Bruce Dehning, Chapman University, Orange, United States, E-mail: bdehning@chapman.edu

Received: December, 2016 1st Revision: March, 2017 Accepted: June, 2017

DOI: $10.14254 / 2071-$ 789X.2017/10-3/19
Nadirov, O., Aliyev, K., Dehning B. (2017). To Work More or Less? The Impact of Taxes and Life Satisfaction on the Motivation to Work in Continental and Eastern Europe. Economics and Sociology, 10(3), 266-280. doi:10.14254/2071-789X.2017/10-3/19

\section{TO WORK MORE OR LESS? THE IMPACT OF TAXES AND LIFE SATISFACTION ON THE MOTIVATION TO WORK IN CONTINENTAL AND EASTERN EUROPE} JEL Classification: H20, J01,
J29

\begin{abstract}
Using country-level data from 2000-2013, we test the relationship between life satisfaction (measured as how people evaluate their life as a whole rather than their current feelings) and the motivation to work (measured as aggregate hours of work). Our hypothesis is that even after controlling for average labor income tax rates in countries with high and low average hours worked, there is a significant negative association between the motivation to work and life satisfaction. The main findings of this paper are that the increase in the motivation to work per employee comes at the expense of life satisfaction, and differences in average tax rates on labor income cannot account for differences in time allocation. Once life satisfaction is included, the hypotheses of previous neoclassical economic studies are almost irrelevant in determining the response of market hours to higher average tax rates on labor income. In line with our assumption, we find a negative relationship between life satisfaction and the motivation to work in the cross-country examinations. In countries with the highest hours worked (Hungary, Estonia), wealth is generally preferred to leisure and in countries with the lowest hours worked (France, Germany), leisure is preferred to wealth.
\end{abstract}

Keywords: motivation to work, labor supply, labor taxes, life satisfaction.

\title{
Introduction
}

Nowadays, there are huge differences between Americans and Europeans in how the motivation to work changes in the labor market. In the 1990s, the average weekly working hours started to fall in Europe, whereas Americans started to work more. Using the average number of weekly hours of work data from the European Statistics database (Eurostat, 2017) and the Organisation for Economic Co-operation and Development (OECD, 2017a), we found that, in 2014, Americans worked 38.6 hours per week in market work (defined as paid time). For example, in the same year, the average number of weekly hours of market work by French workers was 34.4. The comparison between Germany and the United States is similar. 
However, the average weekly working hours were not the same in the early 1970s. Decomposing the weekly hours worked per worker into the weekly hours worked per person, we can observe that Americans were working fewer hours per person, 23.5 per week, on average, while the average number of hours working per person was 24.4 per week in France (see Prescott, 2004; McGrattan and Rogerson, 2004; Hallam and Weber, 2007; for details). Previous studies have tried to find answers to the question, "Why are there differences in the motivation to work between countries and why did it change after the 1970s?" Using cultural differences to answer this question when comparing the United States and European countries is dubious. Around the time of World War I, the motivation to work was lower in the United States than in France and Germany (Huberman, 2004). Then, the motivation to work started to decline in Europe, and by the late 1960s, it was almost the same in the United States and Europe (Huberman, 2004). The aforementioned fluctuations in the history of hours worked shows that simply comparing the motivation to work between the United States and Europe is inappropriate and much remains to be clarified. To the best of our knowledge, this is the first work on the effect of taxes on the motivation to work that examines and compares Continental Europe with Eastern Europe.

Finding deterministic factors influencing the motivation to work has been the subject of intense debate in recent international economic literature. To the best of our knowledge, except for Alesina et al. (2005), most of the papers in this area pay little or no attention to life satisfaction when explaining the motivation to work (Prescott, 2004; Faggio and Nickell, 2007; Rogerson, 2007; Ohanian et al., 2008; Olovsson, 2009; Berger and Heylen, 2011). Our aim in this paper to examine the explanatory power of two factors, average labor income tax rates and life satisfaction, on the motivation to work in Continental and Eastern Europe. The main question we are trying to answer is why the motivation to work in France and Germany fell dramatically, but stayed relatively stable in Hungary and Estonia (see Table 1, below).

In Table 1, we introduce a picture of both weekly and annual hours worked. The interesting point is that there is much variation in annual hours worked compared to weekly hours worked (see Causa, 2009; Chapter 3 in OECD, 2008 for more details). Therefore, one should also be cautious when interpreting the results, as the effect of taxation or other regulatory policies can be overestimated/underestimated due to different measures of dependent variables on hours worked (Causa, 2009). In the empirical model of the present paper, we will refer to the annual hours worked to capture the cross-country differences on work motivation along the intensive margin. To the best of our knowledge, until now only three scholarly works (Faggio and Nickell, 2007; Causa, 2009; Berger and Heylen, 2011) have investigated the intensive margin in hours worked.

Table 1. The patterns of weekly and annual hours worked in Eastern and Continental Europe

\begin{tabular}{ccccccccc}
\hline & \multicolumn{3}{c}{$\begin{array}{c}\text { Average usual weekly } \\
\text { hours worked on the main job }\end{array}$} & \multicolumn{3}{c}{$\begin{array}{c}\text { Average annual hours } \\
\text { actually worked per worker }\end{array}$} \\
\hline & \multicolumn{2}{c}{ Eastern Europe } & \multicolumn{2}{c}{ Continental Europe } & \multicolumn{2}{c}{ Eastern Europe } & \multicolumn{2}{c}{ Continental Europe } \\
\cline { 2 - 9 } & Estonia & Hungary & France & Germany & Estonia & Hungary & France & Germany \\
\hline 1 & 2 & 3 & 4 & 5 & 6 & 7 & 8 & 9 \\
\hline 2000 & 39.9 & 40.7 & 36.1 & 35.7 & 1,978 & 2,033 & 1,535 & 1,452 \\
\hline 2001 & 39.8 & 40.5 & 35.7 & 35.4 & 1,970 & 1,993 & 1,526 & 1,442 \\
\hline 2002 & 39.6 & 40.4 & 35.2 & 35.2 & 1,973 & 2,005 & 1,487 & 1,431 \\
\hline 2003 & 39.4 & 40.2 & 36.2 & 34.8 & 1,978 & 1,978 & 1,484 & 1,425 \\
\hline 2004 & 39.5 & 40.1 & 36.2 & 34.8 & 1,986 & 1,986 & 1,513 & 1,422 \\
\hline 2005 & 39.4 & 40.0 & 36.3 & 34.5 & 2,008 & 1,987 & 1,507 & 1,411 \\
\hline 2006 & 39.5 & 40.1 & 36.3 & 34.5 & 2,001 & 1,984 & 1,484 & 1,425 \\
\hline
\end{tabular}


INTERDISCIPLINARY APPROACH TO ECONOMICS AND SOCIOLOGY

\begin{tabular}{ccccccccc}
\hline 1 & 2 & 3 & 4 & 5 & 6 & 7 & 8 & 9 \\
\hline 2007 & 39.4 & 40.0 & 36.4 & 34.4 & 1,998 & 1,979 & 1,500 & 1,424 \\
\hline 2008 & 39.4 & 39.9 & 36.6 & 34.5 & 1,968 & 1,982 & 1,507 & 1,418 \\
\hline 2009 & 38.7 & 39.6 & 36.5 & 34.6 & 1,831 & 1,963 & 1,489 & 1,373 \\
\hline 2010 & 38.7 & 39.6 & 36.5 & 34.6 & 1,875 & 1,958 & 1,494 & 1,390 \\
\hline 2011 & 38.7 & 39.3 & 36.6 & 34.6 & 1,919 & 1,976 & 1,496 & 1,393 \\
\hline 2012 & 38.7 & 39.3 & 36.5 & 34.6 & 1,886 & 1,889 & 1,490 & 1,375 \\
\hline 2013 & 38.8 & 39.4 & 36.2 & 34.4 & 1,866 & 1,880 & 1,474 & 1,362 \\
\hline
\end{tabular}

Source: OECD (2017a, b).

In the light of this, our paper begins with the basic facts on the motivation to work across countries (Hungary, Estonia, Germany, France, and the United States). The paper provides an ample amount of evidence from both public finance and labor economics to draw certain conclusions. Numerous theoretical and empirical studies have identified a negative relation between tax rates (marginal and average) and labor supply (e.g., Blundell and MaCurdy, 1999; Blundell and Shephard, 2011; Meghir and Phillips, 2008). However, 'labor supply' is not the same as 'the motivation to work'. It comprises a more general explanation in comparison with the motivation to work. When we discuss 'work', we mean work in the market, not work overall; unpaid home production is part of 'non-working time'. Moreover, untaxed ('underground') sector of the economy, including tax avoidance and tax evasion activity, is considered as a 'non-working time'. The simplification of this methodology has also been used by Lindbeck (1982) and Stuart (1981). In this way, our study will contain only 'work versus leisure' phenomena.

Several interesting findings emerge in our paper, among them that differences in the motivation to work to tax-induced income changes are probably linked not only to the size of the average labor income tax rates or to the characteristics of the labor market (culture, unionization, labor market regulations, generous welfare systems, unemployment compensation programs, etc.), but also to other factors that have not yet been sufficiently explored. The primary finding of this paper is perhaps that people who are more balanced in their approach to life are both happier and take more leisure. But a more persuasive story is that the motivation to work has started to decline in Continental Europe, due to high levels of life satisfaction, while in Eastern Europe the motivation to work has started to increase because of low levels of life satisfaction.

The paper is organized as follows: In the next section, we briefly discuss the recent literature in this area and then we develop theory and hypotheses. We then examine the data, including hours worked, average labor income tax rates, and life satisfaction. In the following section, we build an econometric model. The empirical results and interpretation section flows that, and presents quantitative findings. Finally, in the last section, we present our findings and conclusions.

\section{Literature review}

Recently, fervent arguments have been made in the United States and some European Union countries regarding taxation and labor supply. Most of the literature has focused on the impact of differences in labor market institutions. Blanchard and Summers (1986), Bentolila and Bertola (1990), and Blanchard and Jimeno (1995) have focused on the labor supply aspects of the role of institutions and labor market restrictions. Some empirical evidence suggests that the impact of unions, taxes, and employment protection can cause less the motivation to work (Nickell, 1977; Nicoletti and Scarpetta, 2002; Nickell et al., 2003). However, Prescott (2002) 
disputes that differential taxation by itself might cause the differences in the current level of aggregate hours worked.

The first significant work was done by Prescott (2004) who calibrated a growth model to see the differences in the motivation to work between the United States and Europe. Prescott (2004) provided that different marginal tax rates explain the decreasing motivation to work in more advanced industrial countries. Prescott's framework has been followed by numerous studies (e.g., Davis and Henrekson, 2003; Ljungqvist and Sargent, 2006; Ohanian et al., 2008; Chetty et al., 2011; McDaniel, 2011). His idea was defended by the statistical evidence of Davis and Henrekson (2003), who found that in wealthier countries higher tax rates reduce the motivation to work. Alesina, Glaeser, and Sacerdote (2005) found that the impact of taxes on labor supply is negated by unionization management and labor market regulation. Ljungqvist and Sargent (2008) provided that unemployment benefits supplied by governments decrease the labor supply. Ohanian et al. (2008) apply Prescott's methodology to a larger sample of countries over a longer time span and conclude that much of the change in hours worked over time and across countries can be explained by differences tax rates. Conesa and Kehoe (2008) empirically assessed taxes and productivity on the motivation to work in Spain. Their models showed that almost 80 percent of the decrease in the motivation to work can be explained by increasing taxes. Chen et al. (2015) contend that increases in labor taxes and unemployment benefits together explain roughly $75 \%$ of the declining the motivation to work in Europe relative to the United States over the past three decades. Using micro data from the European Social Survey, Mocan and Pogorelova (2015) tested the impact of "culture of leisure" and taxes (average and marginal) on the motivation to work of second-generation immigrants living in 26 European countries. They found that both "culture of leisure" and taxes have an impact on females, but for men the only taxes have an impact on their motivation to work. The findings of Mocan and Pogorelova (2015) show that there is a significant difference between not only Americans and Europeans, but also between European countries. Therefore, we ground our predictions based on two country groups: Continental Europe (Germany, France) and Eastern Europe (Hungary, Estonia).

\section{Theory development and hypothesis}

High tax rates and its impact on the motivation to work is a very broad and interdisciplinary research area. It draws on works from economics, accounting, psychology, and sociology. The topic is of great interest to academics, policy makers, and private-sector institutions worldwide. Because we are introducing psychological and sociological theories in addition to economic theory, this research can make a seminal contribution in the areas of taxation and economics.

To derive the empirical model, we follow theory of the leisure class presented by Veblen (1899), which presented individuals as irrational, economic agents who pursue social status and the prestige that comes from a place in society with little regard to their own satisfaction. Especially, Veblen (1899) criticized contemporary (19th-century) economic theories, and indicated that economists should take into account how individuals behave, socially and culturally, rather than rely upon the abstractions of theoretic deduction to explain the economic behavior of society (Veblen, 1899). On the other hand, in the national tax debate, many ignore the effect of taxes on human motivation (Harriss 1985). But, we know from Maslow's Hierarchy of Needs that individuals must satisfy lower level basic needs before progressing on to meet higher-level growth needs (Maslow, 1954). Once lower basic needs have been reasonably satisfied, the importance of income decreases (Lewis, 1982). That is why both of 
these theories are appealing in determining the differences of hours worked between these countries. Following from the above discussion, it is hypothesized that:

Hypothesis: After controlling for differences in average labor income tax rates between the highest hours worked countries and the lowest hours worked countries, there is a significant negative association between the motivation to work and life satisfaction.

\section{Data: average labor income tax rates, life satisfaction and the motivation to work}

This section presents data on hours worked and the average labor income tax rates across countries. Life satisfaction measures are added to assess the true relationship between hours worked and average labor income tax rates from different perspectives. Our study will focus on the role of those three factors in determining whether it is taxes or life satisfaction that explains the differences in hours worked between these countries.

\subsection{Data on hours worked}

The main goal of this research is to investigate which policy can help clarify the motivation of employees to work. Employee motivation will be measured by the aggregate hours of work. For our example countries, the measure of aggregate hours of work will be the product of two numbers: civilian employment and annual hours of work per person in employment. This methodology was previously used by Ohanian et al. (2008). The employment and hours data are taken from the OECD Labor Statistics Database (OECD, 2017a, b). The sample of countries includes: France, Germany, Hungary, Estonia, and the United States. When we conduct our statistical analysis, the country sample reduces to 4 countries because we measure only differences among the highest hours worked countries (Hungary, Estonia) and the lowest hours worked countries (France, Germany). It is important to note that the hours data are meant to include differences in vacation and statutory holidays, as well as differences in the workweek (Rogerson, 2008). Because these four countries differ in population size, the data is normalized by the size of the population aged 15-65, which is used as a proxy for the number of working-aged individuals. The logic for this is that individuals under 15 are usually full-time students and individuals over the age of 65 are normally retired from market work. The normalization formula in shown in Equation (1):

$$
\mathrm{H}=((\text { Annual hours per employee }) * \text { Employment }) / \text { Population }(15-64)
$$

To simplify comparisons we report all values relative to the US in 2000-2013. Table 2 indicates the resulting distribution of relative hours of work across countries. Examining Table 2 shows that there are considerable differences in hours worked across these four countries, with the lowest hours worked countries (France and Germany) working around 25\% less than their counterparts in the US and the highest hours worked countries (Hungary and Estonia) working around $10 \%$ more than their counterparts in the US.

Table 2. Hours worked relative to the US, 2000-2013

\begin{tabular}{ll}
\hline Low $(<.8)$ & High $(\geq 1.00)$ \\
\hline France $(.74)$ & Hungary $(1.10)$ \\
\hline Germany $(.76)$ & Estonia $(1.09)$ \\
\hline
\end{tabular}

Source: Authors' own compilation. 


\subsection{Calculating average tax rates on labor income}

We know from previous neo-classical growth model studies that general taxes in the economy are divided into four categories: 1) consumption tax; 2) investment tax; 3) capital tax; and 4) labor income tax. The calculation of tax rates provided in this paper are only related to labor income. To be more precise, we shall concentrate on taxes on labor income paid by individuals. The other three taxes are excluded from our research because we want to focus on the average labor income tax rate and its impact on aggregate hours worked. It has been shown that individuals reduce their labor supply significantly more in response to an income tax than to an equivalent consumption tax (Blumkin et al., 2012).

Here, this question can be raised among the readers 'why we are using average labor tax rate'. Because, according to economic theory, income taxes affect the incentives to supply labor by lowering the real wage (Ohanian et al., 2008).

According to economic theory, income taxes affect the incentives to supply labor by lowering the real wage (Ohanian et al., 2008). There are several different tax rates available to choose from when examining these questions, including statutory tax rates, marginal tax rates, and average tax rates. The complexity and diversity of tax exemptions, deductions, and credits make it nearly impossible for researchers to estimate the actual tax burden from information on statutory tax rates, making them unsuitable. Producing time-series and cross-country samples of marginal tax rates is limited by data availability. Therefore, we use average tax rates for labor income. A measure of average tax rates was developed by McDaniel (2007). Tax systems often include different forms of taxation that affect the same tax base. There are three widely used methods for deriving average tax rates.

The first is usually referred to as an effective tax rate. Mendoza et al. (1994) computed the time series of effective tax rates on consumption, capital income, and labor income. They measured these tax rates for G7 countries using information from publicly available data sources. Mendoza et al. (1994) provide a method for calculating average tax rates that does not rely on data from individual tax returns or taxes paid by income bracket. The second method, developed by Prescott (2004), modifies the procedure of Mendoza et al. (1994) for producing the effective marginal tax rate on labor income. McDaniel (2007) developed the third method by producing a series for effective average tax rates on labor income that includes taxes levied on labor, payroll, and consumption for 15 OECD countries from the mid-1950s through the early 2000s. She found that the effective average labor tax rate is around $30 \%$ in the highest hours worked countries, while it is around $50 \%$ in the lowest hours worked countries.

There are some differences in details among these three methodologies. McDaniel's work builds upon the previous estimates of average tax rates across countries by Mendoza et al. (1994) and Prescott (2004). To obtain a correspondence from the actual tax systems to the taxes in the model, we utilize McDaniel's method. Table 3 displays the data categories for tax revenues, domestic income, and private expenditures from OECD National Accounts (OECD, $2017 \mathrm{c}$ ) used to calculate tax rates from 2000 to 2013.

Table 3. SNA 2000-2013 National Account Data

\begin{tabular}{ll}
\hline GDP & Gross Domestic Product \\
\hline TPI & Taxes on production and imports \\
\hline Sub & Subsidies \\
\hline HHTL & Taxes on income and profits (hh) \\
\hline SS & Actual social contributions, receivable (gov) \\
\hline
\end{tabular}

Note: 'hh' denotes a value comes from household accounts and 'gov' from government accounts. Source: McDaniel (2007). 
The average tax rate on labor income $\tau^{h}$ is obtained as in Equation (2):

$$
\tau^{h}=\frac{S S+H H T_{L}}{(1-\theta)(G D P-(T P I-S u b))}
$$

Gollin (2002) found evidence regarding the labor share and that it is roughly constant over countries, in the range of 0.65 and 0.80 . Therefore, we set $1-\theta=0.7$. Following McDaniel (2007), we found that the effective average labor tax rate in the highest hours worked countries (Hungary, Estonia) and the lowest hours worked countries (France, Germany) is around 35$40 \%$, while the same rate is around $20-25 \%$ in the US, as shown in Table 6 in the Appendix. If the average labor tax rates are the same for both the highest and lowest hours worked countries, then an interesting research question is, "What is the key factor that can account for the differences in hours worked, if it is not differences in labor tax rates?" In the next section, we attempt to shed light on this question using data on life satisfaction.

\subsection{Isn't life satisfaction a great thing?}

Life satisfaction measures how people evaluate their life as a whole rather than their current feelings. To measure life satisfaction we used data from Eurobarometer (EC, 2017). Subjects were asked, "On the whole are you very satisfied, fairly satisfied, not very satisfied, or not at all satisfied with the life you lead?" (EC, 2017). When asked to rate their general satisfaction with life on a scale from 0 to 10, people across the OECD gave it an average 6.6 response (EC, 2017). However, life satisfaction is not equally shared across the OECD. Some countries, including Estonia and Hungary, have a relatively low level of overall life satisfaction, with average scores of less than 5.6. At the other end of the scale, scores reach 7.0-7.5 in Germany and France. There is almost no difference in life satisfaction levels between men and women across OECD countries.

\subsection{Descriptive statistics}

The data used in the empirical tests includes four countries, Germany, France, Hungary, and Estonia for the 2000-2013 period by using annual data. Below, Table 4 tabulates descriptive statistics of the model variables.

Table 4. Descriptive statistics of the variables

\begin{tabular}{lccccc}
\hline Variable & Obs. No. & Mean & Maximum & Minimum & Std. Dev. \\
\hline Hour_work & 40 & 1734.03 & 1872.00 & 1566.40 & 122.52 \\
\hline Sat_index & 40 & 2.790 & 3.160 & 2.280 & 0.259 \\
\hline Labor_tax & 40 & 0.369 & 0.390 & 0.354 & 0.012 \\
\hline Rates & 40 & 34.88 & 57.07 & 21.48 & 12.37 \\
\hline Duration & 40 & 0.515 & 0.830 & 0.310 & 0.164 \\
\hline Density & 40 & 12.89 & 22.20 & 5.100 & 5.534 \\
\hline Protection & 40 & 2.328 & 2.866 & 1.587 & 0.345 \\
\hline Dummy & 40 & 0.500 & 1.000 & 0.000 & 0.506 \\
\hline
\end{tabular}

Where: HOURS WORKED $_{t}$ denotes hours worked per employee at time $t ; S A T_{I N D E X_{t}}$ denotes life satisfaction index at time $t ; L A B O R_{T_{A X} t}$ denotes labor income tax at time $t$; and $D U M M Y$ is a binary variable takes the value 1 for the observations from the countries with low working hours (Germany and France), and 0 for those of the countries with high working hours (Hungary, and Estonia)

Source: Authors' own compilation. 


\section{Model building}

Before choosing the empirical estimation method for the intended regression model, an order of integration of the variables should be examined by employing panel unit root tests. Here, two major points might be considered. First, the existence of a unit root problem with model variables should be tested with and without an intercept. Meanwhile, it is noteworthy to identify both the existence of individual and common unit root processes in panel series. To obtain more reliable and robust results several panel unit root tests are applied in this empirical research. This approach also enables us to address some methodological issues not considered in previous studies (Hasanov et al., 2017).

More precisely, we use Levin, Lin, and Chu (2002), Im, Pesaran, and Shin (2003), Breitung (2000) as well as Fisher-ADF and Fisher-PP panel unit root tests of Maddala and Wu (1999). Note that Levin, Lin, and Chu (hereafter LLC) and Breitung assume a common unit root process while Im, Pesaran and Shin (hereafter IPS), Fisher-ADF and Fisher-PP tests assume the individual unit root process in panel data series. Test results provide useful information about the integration properties of the data employed in this research.

To estimate the responsiveness of hours worked per employee to life satisfaction and labor income tax rates, we first employ a panel multiple linear regression model as in equation (3), and second we employ an impulse response analysis based on an unrestricted Vector Autoregressive (VAR) model as in equation (4) below:

$$
\begin{aligned}
& \log \left(\text { HOURS }_{\text {WORKED }_{t}}\right)=\beta_{0}+\beta_{1} * S A T_{\text {INDEX }}+\beta_{2} * S A T_{\text {INDEXX }} * D U M M Y+\beta_{3} * L_{A B B O R_{\text {TAX }}}+ \\
& +\beta_{4} * L A B O R_{\text {TAX }} * D U M M Y+\sum_{i=\cdot}^{i=4} \varphi_{i} * X_{i, t}+\vartheta_{t}
\end{aligned}
$$

and

$$
\begin{aligned}
& \log \left(\text { HOURS }_{\text {WORKED }_{t}}\right)=\theta_{0}+\theta_{1} * \log \left(\text { HOURS }_{\text {WORKED }_{t-1}}\right)+\theta_{2} * \operatorname{SAT}_{\text {INDEX }}+1 \\
& +\sum_{i=1}^{i=4} \delta_{i} * X_{i, t}+\varepsilon_{t}
\end{aligned}
$$

Here, HOURS WORKED $_{t}, S A T_{\text {INDEX }}$, and $L A B O R_{T_{A X}}$ are as defined previously (see Table 4). $X_{i, t}$ covers all institutional variables (benefit replacement rates, unemployment benefit duration, net union density, and employment protection) added to the model to control such effects. Institutional variables used in our regressions are taken from the Database for Institutional Comparisons in Europe (DICE, 2017) (for more information, see Appendix B). The error terms are denoted as $\vartheta_{t}$ and $\varepsilon_{t}$, respectively.

\section{Empirical results and interpretation}

\subsection{Unit root test results}

Table 5 represents panel unit test results for all variables included, with intercept (panel A), and with the trend and intercept (panel B). Assuming the common unit root process, LLC concludes that hours_work, labor_tax, and density are I(0) or stationary at level while the trend is not included. Fisher-ADF, Fisher-PP, and IPS do not reveal any individual unit root process in hours_work, and labor_tax, giving conflicting results. However, at least one test 
rejects the existence of unit root at a 5\% significance level in all variables, except rates and protection.

When the trend is included, LLC test results reject a common unit root process in all variables, except duration. Breitung test reveals weak stationarity, but finds duration $\mathrm{I}(0)$ at the $5 \%$ significance level. To test de-trended individual unit root process, only Fisher-PP unit root test reveals duration $\mathrm{I}(0)$ while protection is found as not stationary at level. For other variables, the existence of an individual unit root process is mostly rejected.

Overall evaluation of unit root tests is that only duration and protection are weak stationary at the level when the series are de-trended. Note that in Nadirov and Aliyev (2016), the impact of both duration and protection over hours_work is not statistically significant. To overcome this issue, here, we decide to run empirical estimations with as well as without these two variables to obtain results that are more reliable.

Table 5. Panel unit root test results

\begin{tabular}{|c|c|c|c|c|c|}
\hline \multicolumn{6}{|c|}{ Panel A: Individual Intercept } \\
\hline & LLC & Breitung & Fisher-ADF & Fisher-PP & IPS \\
\hline & $\mathrm{I}(0)$ & $\mathrm{I}(0)$ & $\mathrm{I}(0)$ & $\mathrm{I}(0)$ & $\mathrm{I}(0)$ \\
\hline Hours_work & $-6.237 * * *$ & - & $21.159 * * *$ & $15.082 * *$ & $-2.314 * *$ \\
\hline Sat_index & -0.799 & - & $12.990 *$ & $23.817 * * *$ & -0.863 \\
\hline Labor_tax & $-7.726 * * *$ & - & $22.777 * * *$ & $16.660 * *$ & $-2.783 * * *$ \\
\hline Rates & -0.317 & - & 10.815 & $12.812^{*}$ & 0.013 \\
\hline Duration & 7.386 & - & 5.674 & $20.771 * * *$ & -0.628 \\
\hline Density & $-5.573 * * *$ & - & $16.404 * *$ & 4.775 & $-1.359^{*}$ \\
\hline Protection & -0.120 & - & 1.389 & 1.837 & 0.583 \\
\hline \multicolumn{6}{|c|}{ Panel B: Individual Intercept and Trend } \\
\hline Hours_work & $-28.939 * * *$ & $-1.450 *$ & $24.699 * * *$ & 10.468 & $-4.075 * * *$ \\
\hline Sat_index & $-2.9900 * * *$ & -1.144 & $13.587^{*}$ & $35.695 * * *$ & -0.509 \\
\hline Labor_tax & $-13.292 * * *$ & $-1.295^{*}$ & $33.728 * * *$ & $28.194 * * *$ & $-2.786^{* * *}$ \\
\hline Rates & $-2.937 * * *$ & $-2.290 * *$ & $13.921 *$ & $16.448 * *$ & -0.524 \\
\hline Duration & 21.340 & $-1.542 * *$ & 2.445 & $18.669 * * *$ & 0.257 \\
\hline Density & $-89.349 * * *$ & $-1.445^{*}$ & $25.738 * * *$ & $21.264 * * *$ & $-12.534 * * *$ \\
\hline Protection & -0.815 & $-1.696^{* *}$ & 2.165 & 1.845 & 0.241 \\
\hline
\end{tabular}

Note: ***, $* *$, and $*$ denote rejection of the null hypothesis at the $1 \%, 5 \%$ and $10 \%$ significance levels respectively. Probabilities of Fisher-ADF and Fisher-PP are computed by using an asymptotic $\chi 2$ distribution while all the rest of the tests assume asymptotic normality. Maximum lag length set to two and optimal length is specified automatically by Schwarz (SC) criterion.

\subsection{Panel OLS regression results}

Table 5 tabulates panel OLS regression results obtained from the estimation of equation (2) in two different modifications. More precisely, two institutional variables (duration and protection) are not included in the panel regression in model (2) while both are added to the estimated model (1). It is noteworthy once to emphasize that dummy is a binary variable included to differentiate the impact of sat_index and labor_tax to the hours_work for the lowand-high working hour countries. 
Table 5. Panel OLS regression results

\begin{tabular}{lll}
\hline Independent variables & Model $(1)$ & Model $(2)$ \\
\hline Sat_index & $0.0889^{* * *}$ & $0.0807^{* * *}$ \\
& $(0.0155)$ & $(0.0102)$ \\
\hline \multirow{2}{*}{ Sat_index*dummy } & $-0.1187^{* * * *}$ & $-0.1153^{* * *}$ \\
\hline \multirow{2}{*}{ Labor_tax } & $(0.0297)$ & $(0.0289)$ \\
\hline \multirow{2}{*}{ Labor_tax*dummy } & 0.2248 & 0.2717 \\
& $(0.2298)$ & $(0.2161)$ \\
\hline \multirow{2}{*}{ Log(Rates) } & $0.6037^{* * *}$ & $0.5794^{* * *}$ \\
\hline \multirow{2}{*}{ Log(Duration) } & $(0.2654)$ & $(0.2590)$ \\
\hline \multirow{2}{*}{ Log(Density) } & $-0.0511^{*}$ & $-0.0571^{* *}$ \\
& $(0.0291)$ & $(0.0233)$ \\
Log(Protection) & -0.0064 & - \\
\hline \multirow{2}{*}{ C } & $(0.0261)$ & $0.0264^{* * *}$ \\
& $0.0286^{* * *}$ & $(0.0055)$ \\
\hline$R$-squared & $(0.0062)$ & - \\
S.E. of regression & -0.0137 & $7.3299^{* * *}$ \\
No. of obs. & $(0.0135)$ & $(0.1412)$ \\
\hline
\end{tabular}

Note: The dependent variable is $\log$ (hours_work). ***, **, and * denote rejection of the null hypothesis at the $1 \%, 5 \%$ and $10 \%$ significance levels respectively. Standard errors for each coefficient are given in parentheses.

Comparing the estimation results in model (1) and model (2) shows no significant impact of excluding duration and protection. Thus, this exclusion does not lead to any statistically significant changes as well as too small of magnitude differences for regression coefficients. Meanwhile, the coefficients of both institutional variables are neither statistically, nor economically, significant as in Nadirov and Aliyev (2016).

Empirical estimations indicate that the impact of sat_index over working hours is statistically significant for both groups, but positive in countries with high working hours while the association is negative in those with low working hours according to our sample. More precisely, in the case of Hungary and Estonia, the average impact of a one unit positive change in sat index increases working hours by $8.07-8.89 \%$ while other variables are assumed to remain the same. For Germany and France, the impact is negative $((0.0889-0.1187) * 100 \%=$ $-2.98 \%$ for the model (1), and $(0.0807-0.1153) * 100 \%=3.46 \%)$ for model (2).

For the impact of labor_tax, for high working hour countries, a $1 \%$ or 0.01 point increase leads to $0.22-0.27 \%$ more work ${ }^{1}$. This impact is significantly higher for countries with low working hours $(0.6037 \%-0.2248 \%=0.3789 \%$ for model $(1)$, and $0.5794 \%-0.2717 \%=0.3077 \%$ for model (2)). For institutional variables, estimation results reveal a statistically significant negative influence of rates and a positive impact of density. The remaining two institutional variables (duration and protection) do not significantly matter for the motivation to work.

\footnotetext{
${ }^{1}$ Note that labor income tax gets a value between 0 and 1 . Here, 1 point means 0.01 . That is why in interpretation we calculate, ceteris paribus, the impact as $0.2248 * 0.01 * 100 \%$.
} 


\subsection{Impulse response analysis}

Because all variables are $\mathrm{I}(0)$, we can run unrestricted VAR to obtain impulse-response simulation results. Note that only hours_work, labor_tax, and sat_index are included as endogenous variables while institutional variables are employed as exogenous. Meanwhile, a binary variable is also added to the exogenous factors in order to control for working hours difference between the two groups.

Simulation findings are refined and support our expectations as well as are in accordance with the panel OLS results (see Figure 1, below). Simulations reveal a positive response in hours worked per employee to one standard deviation in labor income taxation in both cases. Including duration and protection does not significantly matter for this relationship. However, the same inference cannot be made in case of the satisfaction index and hours worked per employee. When the two institutional variables are included in the VAR specification as exogenous factors, the response of work hour per employee to one standard deviation in satisfaction index is negative. When duration and protection are not added, no significant response is observed. These findings are plausible as we found a negative relationship for low working hour countries in panel OLS estimations.
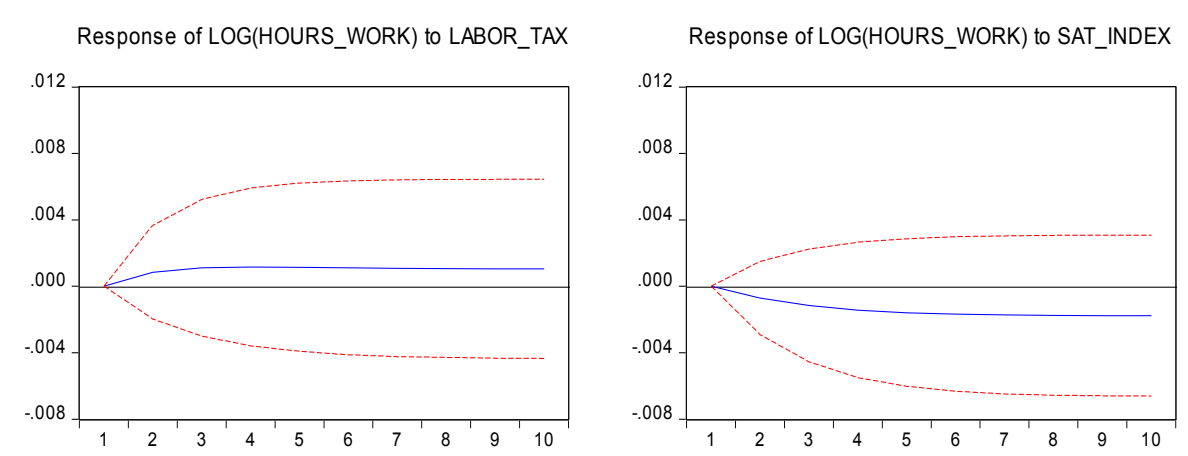

a) While including duration and protection as exogenous variables
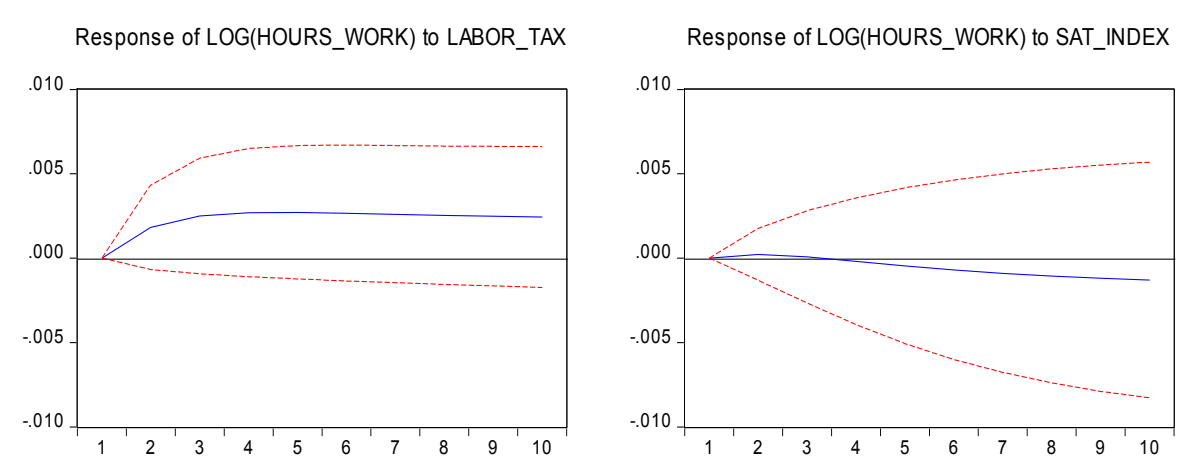

b) Duration and protection are not added to the exogenous variables list.

Figure 1. Impulse-response simulations.

Note: Simulation results are obtained from unrestricted VAR estimation with one lag. There is not autocorrelation problem in residuals according to LM test results.

Source: Author's own calculation.

\section{Conclusion}

In this article, we argue that an empirical approach to the relationship between taxes and the motivation to work should take into account the distinction between the highest hours 
worked countries and the lowest hours worked countries to help generate significant insights. To test this conjecture, we constructed both impulse response analysis based on unrestricted Vector Autoregressive (VAR) model and a panel multiple linear regression model in which countries with high working hours and low working hours enter as separate factors into the process. The econometric model was estimated and tested for four countries (Hungary, Estonia, Germany, and France) over the period 2000-2013. The primary points from these models can be summarized as follows. Increases in life satisfaction exert negative effects on working hours in countries with low working hours, while it has a positive effect on working hours in countries with high working hours. This suggests that the effect of average labor income tax rates on the motivation to work can be assessed differently for societies who are working for normal living standards and societies who are working for social status or other luxury items. For future research, our idea can be tested with poor and rich countries instead of using the classification of countries with high and low working hours. While people in poor countries might have lower life satisfaction, people in rich countries might have greater life satisfaction; this approach can help us to see how people in rich countries behave compared to people in poor countries when average labor income tax rate changes.

\section{Acknowledgement}

The authors would like to thank the participants in the 3rd Global Conference on Business, Economics, Management, and Tourism, 26-28 November 2015, Rome, Italy. The present paper is a revised and extended version of the conference proceedings. Moreover, the authors would like to thank the Internal Grant Agency of FaME for providing financial support to carry out this research. Funding was extended through: TBU No. IGA/FaME/2017/018 "Income tax and the motivation to work".

\section{References}

Alesina, A., Glaeser, E., \& Sacerdote, B. (2005). Work and leisure in the United States and Europe: why so different? NBER macroeconomics annual, 20, 1-64.

Bentolila, S., \& Bertola, G. (1990). Firing costs and labor demand: how bad is eurosclerosis? The Review of Economic Studies, 57(3), 381-402.

Berger, T., \& Heylen, F. (2011). Differences in hours worked in the OECD: institutions or fiscal policies? Journal of Money, Credit and Banking, 43(7), 1333-1369.

Blanchard, O. J., \& Summers, L. H. (1986). Hysteresis and the European unemployment problem. NBER macroeconomics annual, 1, 15-78.

Blanchard, O., \& Jimeno, J. F. (1995). Structural unemployment: Spain versus Portugal. The American Economic Review, 85(2), 212-218.

Blumkin, T., Ruffle, B. J., \& Ganun, Y. (2012). Are income and consumption taxes ever really equivalent? Evidence from a real-effort experiment with real goods. European Economic Review, 56(6), 1200-1219.

Blundell, R., \& MaCurdy, T. (1999). Labor supply: A review of alternative approaches. Handbook of labor economics, 3, 1559-1695.

Blundell, R., \& Shephard, A. (2011). Employment, hours of work and the optimal taxation of low-income families. The Review of Economic Studies, rdr034.

Breitung, J. (2001). The local power of some unit root tests for panel data. In: Nonstationary panels, panel cointegration, and dynamic panels (pp. 161-177). Emerald Group Publishing Limited. 
Causa, O. (2009). The policy determinants of hours worked across OECD countries. OECD Journal. Economic Studies, $2009(1), 9$.

Chen, B. L., Hsu, M., \& Lai, C. F. (2015). Relative Effects of Labor Taxes and Unemployment Benefits on Hours Worked Per Worker and Employment. Pacific Economic Review, 20(2), 282-309.

Chetty, R., Guren, A., Manoli, D., Weber, A., Sargent, T. J., Rogerson, R., ... \& Yagan, D. (2011). Are Micro and Macro Labor Supply Elasticities Consistent? A. In: Review of Evidence on the Intensive and Extensive Margins, American Economic Review: Papers and Proceedings, 101(3), 471-475.

Conesa, J. C., \& Kehoe, T. J. (2005). Productivity, taxes and hours worked in Spain, 19702003. Manuscript, University of Minnesota.

Davis, S. J., \& Henrekson, M. (2004). Tax effects on work activity, industry mix and shadow economy size: Evidence from rich-country comparisons (No. w10509). National Bureau of Economic Research.

DICE (2017). Labor Market. Online available at http://www.cesifogroup.de/ifoHome/facts/DICE/DICE-Search.html?DICEsearch.facet_isArchived=false.

Eurostat (2017). Hours worked per week of full-time employment. http://ec.europa.eu/eurostat/tgm/table.do?tab=table\&init $=1 \&$ language $=$ en $\&$ pcode $=\operatorname{tps} 00$ $071 \&$ plugin $=1$.

European Commission (2017). Eurobarometer Interactive. Life satisfaction. Online available at http://ec.europa.eu/commfrontoffice/publicopinion/index.cfm/Chart/index.

Faggio, G., \& Nickell, S. (2007). Patterns of work across the OECD. The Economic Journal, 117(521), F416-F440.

Gollin, D. (2002). Getting income shares right. Journal of political Economy, 110(2), 458-474.

Hallam, A., \& Weber, E. J. (2007). Labor taxes and work hours in Australia.

Harriss, L. (1985). Taxation, Incentives and Disincentives, and Human Motivation. American Journal of Economics and Sociology, 44(2), 129-136.

Hasanov, F., Bulut, C., \& Suleymanov, E. (2017). Review of energy-growth nexus: A panel analysis for ten Eurasian oil exporting countries. Renewable and Sustainable Energy Reviews, 73, 369-386.

Huberman, M. (2004). Working hours of the world unite? New international evidence of worktime, 1870-1913. Journal of Economic History, 64(4), 964-1001.

Im, K. S., Pesaran, M. H., \& Shin, Y. (2003). Testing for unit roots in heterogeneous panels. Journal of econometrics, 115(1), 53-74.

Levin, A., Lin, C. F., \& Chu, C. S. J. (2002). Unit root tests in panel data: asymptotic and finitesample properties. Journal of econometrics, 108(1), 1-24.

Lewis, A. (1982). The psychology of taxation. Blackwell.

Lindbeck, A. (1982). Tax effects versus budget effects on labor supply. Economic inquiry, 20(4), 473-489.

Ljungqvist, L., Sargent, T. J., Blanchard, O., \& Prescott, E. C. (2006). Do Taxes Explain European Employment? Indivisible Labor, Human Capital, Lotteries, and Savings (with Comments and Discussion). NBER macroeconomics annual, 21, 181-246.

Ljungqvist, L., \& Sargent, T. J. (2008). Taxes, benefits, and careers: Complete versus incomplete markets. Journal of Monetary Economics, 55(1), 98-125.

Maddala, G. S., \& Wu, S. (1999). A comparative study of unit root tests with panel data and a new simple test. Oxford Bulletin of Economics and statistics, 61(S1), 631-652.

McGrattan, E. R., \& Rogerson, R. (2004). Changes in hours worked, 1950-2000. Federal Reserve Bank of Minneapolis Quarterly Review, 28(1), 14-33. 
Maslow, A. H. (1954). The instinctoid nature of basic needs. Journal of Personality, 22(3), 326347.

Meghir, C., \& Phillips, D. (2010). Labor supply and taxes. Dimensions of Tax Design: The Mirrlees Review, 202-74.

Mendoza, E. G., Razin, A., \& Tesar, L. L. (1994). Effective tax rates in macroeconomics: Cross-country estimates of tax rates on factor incomes and consumption. Journal of Monetary Economics, 34(3), 297-323.

McDaniel, C. (2007). Average tax rates on consumption, investment, labor and capital in the OECD 1950-2003. Manuscript, Arizona State University, 1960-2004.

Mocan, N. H., \& Pogorelova, L. (2015). Why work more? The impact of taxes, and culture of leisure on labor supply in Europe (No. w21297). National Bureau of Economic Research.

Nadirov, O., \& Aliyev, K. (2016). The motivation to work, Labor Income Taxes and Life Satisfaction: Hungary, Estonia, Continental Europe and the United States. Procedia Economics and Finance, 39, 373-379.

Nickell, S. (1997). Unemployment and labor market rigidities: Europe versus North America. The Journal of Economic Perspectives, 11(3), 55-74.

Nickell, S., Nunziata, L., Ochel, W., \& Quintini, G. (2003). The Beveridge Curve, Unemployment and Wages in the OECD from the 1960s to the 1990s (pp. 394-431). Princeton: Princeton University Press.

Nicoletti, G., \& Scarpetta, S. (2001, June). Interactions between product and labor market regulations: do they affect employment? Evidence from OECD countries. In: Conference on "Labor Market Institutions and Economic Outcomes." Lisbon: Bank of Portugal.

OECD (2008). Going for Growth, Paris.

OECD (2017a). OECD statistics - Average usual weekly hours worked on the main job. Online available at https://stats.oecd.org/Index.aspx?DataSetCode $=$ ANHRS.

OECD (2017b). OECD statistics - Average annual hours actually worked per worker. Online available at https://stats.oecd.org/Index.aspx?DataSetCode $=$ ANHRS.

OECD (2017c). OECD statistics - National Accounts at Glance. Online available at https://stats.oecd.org/Index.aspx?DataSetCode = NAAG.

Ohanian, L., Raffo, A., \& Rogerson, R. (2008). Long-term changes in labor supply and taxes: Evidence from OECD countries, 1956-2004. Journal of Monetary Economics, 55(8), $1353-1362$.

Olovsson, C. (2009). Why do Europeans work so little? International Economic Review, 50(1), $39-61$.

Prescott, E. C. (2002). Prosperity and depression. The American Economic Review, 92(2), 1-15.

Prescott, E. C. (2004). Why do Americans work so much more than Europeans? (No. w10316). National Bureau of Economic Research.

Rogerson, R. (2007). Taxation and market work: is Scandinavia an outlier? Economic theory, $32(1), 59-85$.

Rogerson, R. (2008). Structural transformation and the deterioration of European labor market outcomes. Journal of political Economy, 116(2), 235-259.

Stuart, C. E. (1981). Swedish tax rates, labor supply, and tax revenues. Journal of Political Economy, 89(5), 1020-1038.

Veblen, T. (1899). The theory of the leisure class: An economic study in the evolution of institutions. Macmillan. 


\section{Appendix}

Appendix A.

Table 6. Average Tax on Labor, $\tau^{\mathrm{h}}$

\begin{tabular}{lccccc}
\hline Years & Estonia & France & Germany & Hungary & United States \\
\hline 2000 & 0.359 & 0.363 & 0.385 & 0.390 & 0.239 \\
\hline 2001 & 0.362 & 0.360 & 0.380 & 0.374 & 0.237 \\
\hline 2002 & 0.356 & 0.354 & 0.379 & 0.370 & 0.215 \\
\hline 2003 & 0.355 & 0.356 & 0.379 & 0.368 & 0.205 \\
\hline 2004 & 0.358 & 0.363 & 0.381 & 0.365 & 0.238 \\
\hline 2005 & 0.363 & 0.361 & 0.380 & 0.386 & 0.236 \\
\hline 2006 & 0.358 & 0.355 & 0.383 & 0.384 & 0.215 \\
\hline 2007 & 0.360 & 0.354 & 0.382 & 0.382 & 0.210 \\
\hline 2008 & 0.359 & 0.361 & 0.385 & 0.390 & 0.240 \\
\hline 2009 & 0.364 & 0.360 & 0.382 & 0.388 & 0.242 \\
\hline 2010 & 0.358 & 0.359 & 0.381 & 0.380 & 0.239 \\
\hline 2011 & 0.361 & 0.357 & 0.379 & 0.383 & 0.243 \\
\hline 2012 & 0.359 & 0.362 & 0.388 & 0.396 & 0.241 \\
\hline 2013 & 0.363 & 0.360 & 0.386 & 0.388 & 0.238 \\
\hline
\end{tabular}

Source: Author's own calculation.

\section{Appendix B.}

Table 7. Institutional variables

- Employment protection. This variable is higher the stricter the employment protection legislation, with a range $\{0,2\}$.

- Net union density. This variable measures the fraction of workers that were union members over the sample period covered.

- Benefit replacement rates. This variable measures the percentage of (average before tax) earnings covered through unemployment and social insurance programs.

- Benefit duration. This variable is a proxy for the duration of unemployment benefit specified above. A value of zero indicates that the unemployment benefit provision stops within the first year. A value of one indicates that unemployed receive the amount defined in BRR for five years.

Source: Author's own elaboration based on Ohanian et al., 2008. 